\title{
Bacterial growth in deep-sea sediment trap and boxcore samples
}

\author{
Jody W. Deming \\ Chesapeake Bay Institute and Department of Biology, The Johns Hopkins University, 4800 Atwell Road, Shady Side, \\ Maryland 20764, USA
}

\begin{abstract}
This study was to determine whether heterotrophic bacteria associated with deep-sea particulates are adapted more to the moderate temperatures and pressures of surface waters or to the extremes of the deep sea, and how such microorganisms respond to substrate enrichment. Samples of sinking particulates, fecal pellets, and deposited sediments were collected in bottom-moored sediment traps and boxcores at station depths of 1850,4120 , and $4715 \mathrm{~m}$ in the North Atlantic. Homogenized seawater suspensions of samples were incubated for 2 to $7 \mathrm{~d}$ under both shallow and deep-sea temperatures and pressures, with and without substrate enrichment (yeast extract or chitin). Increases in total bacterial number or percent dividing cells were measured by epifluorescence microscopy. Probable origins of bacteria in a given sample were evaluated according to temperature and pressure regimes affording bacterial growth. With a few exceptions, results indicated a predominance of shallow water bacteria in sediment-trap, but not boxcore, samples and an increasingly significant fraction of deep-sea bacteria, adapted to low temperature and elevated pressure, in fecal pellet samples trapped at increasing depth. Under deep-sea conditions, bacterial doubling times in sediment core samples were weeks or months, regardless of substrate enrichment, while in some trap samples were days $(>1.5)$ without enrichment, and hours ( 7.4 to 14$)$ with enrichment. Doubling times of barophilic bacteria, isolated in pure culture from the deeper trap and core samples, ranged from 6 to $13 \mathrm{~h}$ under in situ temperature and pressure. These findings suggest that particulate organic matter, prior to its burial in abyssal sediments, is altered by indigenous, deep-sea bacteria, some of which are capable of rapid activity at low temperature and elevated pressure.
\end{abstract}

\section{INTRODUCTION}

Recent investigations of particulate matter settling through the oceanic water column have revealed subsurface areas of intense microbial activity that is mediated by indigenous bacteria adapted to in situ conditions, and not by surface-derived microorganisms that have settled with the particulates (Fellows et al. 1981, Fuhrman \& Azam 1983, Gowing \& Silver 1983, Karl et al. 1984, Silver et al. 1984). These findings have extended to about $2000 \mathrm{~m}$, the depth at which in situ microbial activities are known to contribute significantly to the recycling of surface productivity and the nutritional support of aphotic pelagic ecosystems. To what greater ocean depths such microbial activity may occur is not known.

Most of the available data from the abyssopelagic environment, which is based on seawater samples and not collections of sinking particulates, indicate that microbial activities are reduced by orders of mag nitude relative to shallower environments, and that elevated pressures act to keep rates low (Jannasch \& Taylor 1984). Thus, it has appeared that the activities of surface-derived bacteria, which are known to be inhibited by deep-sea temperatures and pressures (Wirsen \& Jannasch 1975, Jannasch \& Taylor 1984), dominate over any locally-adapted microorganisms that may occur at great depth. Otherwise, pressureenhanced or barophilic microbial activities would have been measured regularly in deep-sea samples. Instead, such activity has been detected only in invertebrate guts (Schwarz et al. 1976, Deming et al. 1981, Deming \& Colwell 1982), with some preliminary evidence that barophilic activity may also occur in the abyssopelagic environment in sediments and in association with fecal pellets (Deming \& Colwell unpubl.).

To understand more fully the role of bacteria in altering the organic carbon that fuels the deep-sea benthos (Rowe \& Gardner 1979, Rowe \& Deming in press), it is important to know if intense areas of in situ 
microbial activity, similar to those detected above $2000 \mathrm{~m}$, also occur in association with particulate matter descending into the benthic boundary layer. To this end, sinking particulates and deposited sediments were collected in sediment traps and cores at station depths of 1850 (similar to the maximum oceanic depth already studied by others), 4120 , and $4715 \mathrm{~m}$ in the North Atlantic. Conclusions about the origin of bacteria in these samples and their potential for rapid activity in situ are based on relative rates of bacterial growth, as measured in homogenized seawater suspensions incubated under shallow water and deep-sea temperatures and pressures, with and without enrichment with yeast extract or chitin.

\section{MATERLALS AND METHODS}

Sample collection. Samples were collected aboard the French Research Vessel 'Jean Charcot' at station depths of $4120 \mathrm{~m}\left(47^{\circ} 35^{\prime} \mathrm{N}, 9^{\circ} 41^{\prime} \mathrm{W}\right)$ and $4715 \mathrm{~m}$ $\left(46^{\circ} 31^{\prime} \mathrm{N}, 10^{\circ} 27^{\prime} \mathrm{W}\right)$ in the Bay of Biscay during the Biogas expedition of September 1981. Additional samples were collected aboard NOAA Ship 'Mt. Mitchell' at a station depth of $1850 \mathrm{~m}\left(72^{\circ} 26^{\prime} \mathrm{N}, 38^{\circ} 57^{\prime} \mathrm{W}\right)$ off the US East Coast during the NEMP cruise of September 1983. At the $4120 \mathrm{~m}$ station, sinking particulates were collected in a $40 \mathrm{l}$ cylindrical sediment trap (described by Rowe $\&$ Gardner 1979), moored $200 \mathrm{~m}$ above the sea floor. At the $4715 \mathrm{~m}$ station, a larger cone-shaped trap (described by Sibuet et al. 1984) was deployed $20 \mathrm{~m}$ above the seafloor. Both traps were open at depth for $8 \mathrm{~d}$ and sealed upon command prior to ascent and recovery. The temperature of the entrapped seawater upon recovery was about $6^{\circ} \mathrm{C}$ in the first trap and $2.8^{\circ} \mathrm{C}$ in the second. For a shallow water comparison, a Rowe trap was floated for $8 \mathrm{~h}$ at a depth of $20 \mathrm{~m}$ below sea surface at the $4120 \mathrm{~m}$ station. Water temperature upon recovery was $15.5^{\circ} \mathrm{C}$. At the $1850 \mathrm{~m}$ station, particulates were collected in a Rowe trap moored $10 \mathrm{~m}$ above the seafloor for $3 \mathrm{~d}$ with a recovery temperature of $13.8^{\circ} \mathrm{C}$. Surface seawater at that site measured $25^{\circ} \mathrm{C}$.

At the 4120 and $4715 \mathrm{~m}$ stations, cold $\left(6.5\right.$ and $\left.5.5^{\circ} \mathrm{C}\right)$ sediment samples were retrieved using a $0.25 \mathrm{~m}^{2}$ boxcore. After careful siphoning to remove overlying seawater, surface sediment was sampled to a depth of $1 \mathrm{~cm}$ using a sterile spatula. At the $1850 \mathrm{~m}$ station, equally cold sediment was obtained by gravity corer and subsampled aseptically at depths of 1,5 , and $15 \mathrm{~cm}$ after core extrusion.

Sample treatment and analysis. All trap and core samples were kept at $<3^{\circ} \mathrm{C}$ (in a refrigerated laboratory or using ice baths), immediately after recovery and during the following procedures. Particulates from each trap sample were examined under a dissecting microscope to locate and remove individual fecal pel- lets, ranging in length from 100 to $1000 \mu \mathrm{m}$, using a sterile Pasteur pipet. Each pellet was rinsed twice by sequential transfer into sterile seawater (SSW; $0.2 \mu \mathrm{m}$ filtered, autoclaved seawater collected by Niskin bottle from a depth of $4700 \mathrm{~m}$ ) before being pooled in 1 tube and homogenized, using a hand-operated tissue homogenizer. Fecal pellet suspensions, prepared from the subsurface trap and bottom-moored traps at the 1850,4120 , and $4715 \mathrm{~m}$ stations, contained 2, 24, 28 , and 24 pellets, respectively. An undiluted, homogenized seawater suspension of the complete particle collection from the $1850 \mathrm{~m}$ station was also prepared. Sediment samples were diluted 1:5 (wet wt:vol) in SSW from the appropriate station and mixed by vortex.

Portions of each of the 10 sample suspensions prepared for this study were fixed immediately in $2 \%$ formaldehyde for later determination of total bacterial number $\mathrm{ml}^{-1}$ by acridine orange staining and epifluorescence microscopy, using the methods of Hobbie et al. (1977) as applied to sediment samples by Deming $\&$ Colwell (1982). Bacterial concentrations in sediment samples were normalized to $\mathrm{g}^{-1}$ dry wt sediment, after determining percent water content from subsamples dried at $60^{\circ} \mathrm{C}$ for $18 \mathrm{~h}$. The total number of bacteria $\mathrm{g}^{-1}$ dry wt fecal pellet was calculated, using Honjo's estimate, from a study of several hundred deep-sea fecal pellets, that the dry weight of a pellet in the same size class as those used in this study is $3.2 \mu \mathrm{g}$ (Honjo 1978).

Half of the remaining (unfixed) volume of each sample suspension from the 4120 and $4715 \mathrm{~m}$ stations was enriched with $0.2 \mu \mathrm{m}$ filtered, autoclaved yeast extract (YE) to a final concentration of $0.025 \%$. Replicate portions of the enriched and unenriched samples were then loaded into sterile plastic syringes and incubated for $2 \mathrm{~d}$ at $22^{\circ} \mathrm{C}$ and $1 \mathrm{~atm}$, simulating approximate sea surface conditions; at $3^{\circ} \mathrm{C}$ and 400,420 , or 470 atm in pressure vessels, simulating in situ conditions at depth of collection; and at $3{ }^{\circ} \mathrm{C}$ and $1 \mathrm{~atm}$ to differentiate pressure from temperature effects. Subsamples were fixed in $2 \%$ formaldehyde before and after incubation for later analysis by epifluorescence microscopy.

Sample suspensions from the $1850 \mathrm{~m}$ station were split into 5 aliquots, 4 of which were supplemented with YE to a final concentration of $0.001,0.01$, or $0.1 \%$, or with a solution of chitin, purified from squid pens and added to a final concentration of about $3 \%$ (wet wt:vol). Replicate portions of each enriched and unenriched aliquot were then incubated under 3 sets of conditions, similar to those described above except that room (and sea surface) temperature was warmer $\left(25^{\circ} \mathrm{C}\right)$ and simulated in situ pressure was lower $(180 \mathrm{~atm})$. Subsamples were fixed for microscopy at 0 , 2 , and $5 \mathrm{~d}$ for sediment trap samples and at 0,3 , and $7 \mathrm{~d}$ for core sediments. Separate pressure vessels were used for each incubation period. 
The total number and the number of dividing bacteria $\mathrm{ml}^{-1}$ were determined by epifluorescence microscopy for each fixed subsample from these incubation experiments. Standard error (SE) averaged $66 \%$ for total counts of $<10^{6}$ bacteria $\mathrm{ml}^{-1}$, and $16 \%$ for those $>10^{6}$ bacteria $\mathrm{ml}^{-1}$. Counting procedures allowed detection of dividing cells if they were present in numbers $>0.5 \%$ of the total count. For $2 \mathrm{~d}$ end-point experiments in which the total bacterial number increased significantly (>2SE) above starting level, bacterial doubling time was calculated assuming a linear increase during incubation. For 5 and $7 \mathrm{~d}$ timecourse experiments, doubling times were calculated using linear regression analysis if stationary phase had not been reached by the end of the experiment and the correlation coefficient ( $r$ ) was $>0.800$ ( $\mathrm{r}$ averaged 0.962). If growth was rapid and maximum yield attained by the end of the first incubation interval, the experiment was treated as an end-point experiment, again assuming a linear increase. Doubling times determined in this manner may be conservative, since the possibility of an initial lag period followed by more rapid growth cannot be taken into account. The longer time-course experiments would have revealed a lag period of 2 or $3 \mathrm{~d}$, but no such lag was evident in experiments where growth occurred. If no significant growth $(<2 \mathrm{SE})$ was detected in either end-point or time-course experiments, but the end percentage of dividing cells had increased above starting level, the net gain was interpreted as an index of unusually slow or incipient bacterial growth

Pure culture work. Replicate $0.1 \mathrm{ml}$ aliquots of suspensions prepared from trap and boxcore samples from the 4120 and $4715 \mathrm{~m}$ stations were inoculated into each of 4 silica gel pour tubes, prepared according to Dietz \& Yayanos (1978). Inoculated tubes were sealed with parafilm and incubated in pressure vessels at $3^{\circ} \mathrm{C}$ and 410 or $470 \mathrm{~atm}$ for $3 \mathrm{wk}$. Upon decompression, colonyforming units were selected at random and purified, using a purification scheme that involved 2 complete serial transfers from gel to 2216 broth (Difco) to new gel, using a $10 \mathrm{~d}$ culturing period at $2^{\circ} \mathrm{C}$ and the appropriate in situ pressure after each transfer into gel or broth. (One colony was obtained from the subsurface trap sample, but it failed to grow at $2^{\circ} \mathrm{C}$ and $400 \mathrm{~atm}$ upon the first transfer.) Growth rates at $2^{\circ} \mathrm{C}$ and hydrostatic pressures of 1 to 816 atm were determined for 6 of the purified bacterial stains (designated BBS2 and 3 for $4120 \mathrm{~m}$ surface sediment isolates, BBDT1 and 2 for $3920 \mathrm{~m}$ fecal pellet isolates, and BBP5 and 6 for $4695 \mathrm{~m}$ fecal pellet isolates) using methods described by Deming et al. (1984). Also included in this pure culture work were 2 bacterial isolates (BBG3 and 4) obtained from the hindgut contents of an abyssal holothurian (Psychropotes sp.) collected at the $4120 \mathrm{~m}$ station and dissected according to techniques described by Deming \& Colwell (1982).

\section{RESULTS}

Bacterial concentrations in fecal pellet samples, collected near the seafloor, and in all sediment samples are listed in Table 1. The total number of bacteria $\mathrm{g}^{-1}$ in fecal pellets was 9 to 72 times greater than that measured in underlying surface sediments. Bacterial concentrations in sediments decreased linearly with depth in the sediment core $(r=0.950)$ and with station depth $(r=0.998)$. The concentration of bacteria in fecal pellets from the $20 \mathrm{~m}$ subsurface trap at the $4120 \mathrm{~m}$ station $\left(3.07 \times 10^{10}\right.$ bacteria $^{-1}$ dry weight $)$ was comparable to that determined for the deep-sea collections of fecal pellets (Table 1). The undiluted, homogenized seawater suspension of the complete particle collection from the $1850 \mathrm{~m}$ station contained $1.44 \times 10^{8}$ bacteria $\mathrm{I}^{-1}$, a concentration about 20 times higher than that reported in seawater from similar depths (Carlucci \& Williams 1978, Williams et al. 1980).

Results of growth studies using seawater suspen-

Table 1. Total number of bacteria $\mathrm{g}^{-1}$ in fecal pellet and sediment samples. Bacteria in sample suspensions were enumerated by acridine orange staining and epifluorescence microscopy and normalized to $\mathrm{g}^{-1}$ dry wt sediment. For fecal pellet samples, bacteria $\mathrm{g}^{-1}=$ total number bacteria in homogenized suspension $\div$ number pellets $\div 3.2 \times 10^{-6} \mathrm{~g}$, the dry wt of a $200 \mu \mathrm{m}$ pellet as determined by Honjo (1978)

\begin{tabular}{|c|c|c|c|c|}
\hline Sample & $\begin{array}{c}\text { Depth above }(+) \\
\text { or below }(-) \text { seafloor }\end{array}$ & $1850 \mathrm{~m}$ & $\begin{array}{l}\text { Station depth } \\
\quad 4120 \mathrm{~m}\end{array}$ & $4715 \mathrm{~m}$ \\
\hline $\begin{array}{l}\text { Fecal pellets } \\
\text { Fecal pellets }\end{array}$ & $\begin{array}{l}+200 \mathrm{~m} \\
+\quad 10 \mathrm{or} 20 \mathrm{~m}\end{array}$ & $8.59 \times 10^{9}$ & $3.06 \times 10^{10}$ & $1.71 \times 10^{10}$ \\
\hline $\begin{array}{l}\text { Sediment } \\
\text { Sediment } \\
\text { Sediment }\end{array}$ & $\begin{array}{l}-\quad 1 \mathrm{~cm} \\
-\quad 5 \mathrm{~cm} \\
-\quad 15 \mathrm{~cm}\end{array}$ & $\begin{array}{l}9.41 \times 10^{8} \\
4.24 \times 10^{8} \\
2.50 \times 10^{7}\end{array}$ & $4.26 \times 10^{8}$ & $3.34 \times 10^{8}$ \\
\hline
\end{tabular}


Table 2. Doubling time of total bacterial number in seawater suspensions of homogenized fecal pellets and surface sediments from near-surface water and station depths of 4120 and $4715 \mathrm{~m}$

\begin{tabular}{|c|c|c|c|c|c|}
\hline \multirow{2}{*}{ Sample } & \multirow[t]{2}{*}{ Collection depth $(\mathrm{m})$} & \multicolumn{2}{|c|}{ Incubation conditions } & \multicolumn{2}{|c|}{ Bacterial doubling time $(h)^{a}$} \\
\hline & & Temperature $\left({ }^{\circ} \mathrm{C}\right)$ & Pressure (atm) & no additions & $0.025 \% \mathrm{YE}$ added \\
\hline $\begin{array}{l}\text { Fecal } \\
\text { pellets }\end{array}$ & 20 & $\begin{array}{r}22 \\
3 \\
3\end{array}$ & $\begin{array}{r}1 \\
1 \\
400\end{array}$ & $\begin{array}{l}18 \\
\mathrm{NG} \\
\mathrm{NG}\end{array}$ & $\begin{array}{l}3.8 \\
N G \\
N G\end{array}$ \\
\hline $\begin{array}{l}\text { Fecal } \\
\text { pellets }\end{array}$ & $\begin{array}{c}3920 \\
\text { (200 m above seafloor) }\end{array}$ & $\begin{array}{r}22 \\
3 \\
3\end{array}$ & $\begin{array}{r}1 \\
1 \\
400\end{array}$ & $\begin{array}{l}9.0 \\
\text { NG }(1 \%) \\
\text { NG }\end{array}$ & $\begin{array}{l}6.1 \\
13 \\
N G(17 \%)\end{array}$ \\
\hline $\begin{array}{l}\text { Fecal } \\
\text { pellets }\end{array}$ & $\begin{array}{c}4695 \\
\text { (20 m above seafloor) }\end{array}$ & $\begin{array}{r}22 \\
3 \\
3\end{array}$ & $\begin{array}{r}1 \\
1 \\
470\end{array}$ & $\begin{array}{l}\text { NG }(1 \%) \\
\text { NG } \\
\text { NG }(4 \%)\end{array}$ & $\begin{array}{l}7.4 \\
12 \\
13\end{array}$ \\
\hline Sediment & $\begin{array}{c}4120 \\
(1 \mathrm{~cm} \text { below surface })\end{array}$ & $\begin{array}{r}22 \\
3 \\
3\end{array}$ & $\begin{array}{r}1 \\
1 \\
420\end{array}$ & $\begin{array}{l}\mathrm{NG} \\
\mathrm{NG} \\
\mathrm{NG}\end{array}$ & $\begin{array}{l}\mathrm{NG} \\
\mathrm{NG} \\
\mathrm{NG}\end{array}$ \\
\hline Sediment & $\begin{array}{c}4715 \\
(1 \mathrm{~cm} \text { below surface) }\end{array}$ & $\begin{array}{r}22 \\
3 \\
3\end{array}$ & $\begin{array}{r}1 \\
1 \\
470\end{array}$ & $\begin{array}{l}\mathrm{NG} \\
\mathrm{NG} \\
\mathrm{NG}\end{array}$ & $\begin{array}{l}12 \\
\mathrm{NG} \\
\mathrm{NG}\end{array}$ \\
\hline $\begin{array}{l}\text { a Based on a } \\
\text { significantly } \\
\text { YE = yeast } \\
\mathrm{NG}=\text { no gr } \\
\text { percentage }\end{array}$ & $\begin{array}{l}\text { ndpoint experiment in w } \\
\text { ve starting level } \\
\text { ct } \\
\text { i no significant increase } \\
\text { iding cells increased abo }\end{array}$ & $\begin{array}{l}\text { ch total bacterial } \\
+2 \mathrm{SE} \text { ) in bacteri } \\
\text { e starting level, } n\end{array}$ & $\begin{array}{l}\text { aber, determine } \\
\text { amber above st } \\
\text { ain in percenta }\end{array}$ & $\begin{array}{l}\text { pifluorescence } \\
\text { level. For NG } \\
\text { loted parenth }\end{array}$ & $\begin{array}{l}\text { icroscopy, increased } \\
\text { speriments in which } \\
\text { cally }\end{array}$ \\
\hline
\end{tabular}

Table 3. Doubling time of total bacterial number in seawater suspensions of homogenized fecal pellets, other particulates, and sediments from a station depth of $1850 \mathrm{~m}$

\begin{tabular}{|c|c|c|c|c|c|c|c|c|}
\hline \multirow{2}{*}{ Sample } & \multirow{2}{*}{$\begin{array}{l}\text { Collection } \\
\text { depth }(\mathrm{m})\end{array}$} & \multicolumn{2}{|c|}{ Incubation conditions } & \multicolumn{5}{|c|}{ Bacterial doubling time $(\mathrm{h})^{\mathrm{a}}$} \\
\hline & & $\begin{array}{l}\text { Tempera- } \\
\text { ture }\left({ }^{\circ} \mathrm{C}\right)\end{array}$ & $\begin{array}{l}\text { Pressure } \\
\text { (atm) }\end{array}$ & $\begin{array}{c}\text { No } \\
\text { additions }\end{array}$ & $\begin{array}{c}0.001 \% \text { YE } \\
\text { added }\end{array}$ & $\begin{array}{c}0.01 \% \text { YE } \\
\text { added }\end{array}$ & $\begin{array}{l}0.1 \% \text { YE } \\
\text { added }\end{array}$ & $\begin{array}{l}3 \% \text { chitin } \\
\text { added }\end{array}$ \\
\hline Fecal pellets & $\begin{array}{l}1840 \\
(10 \mathrm{~m} \text { above } \\
\text { sea floor) }\end{array}$ & $\begin{array}{r}25 \\
3 \\
3\end{array}$ & $\begin{array}{r}1 \\
1 \\
180\end{array}$ & $\begin{array}{l}12 \\
\text { NG } \\
\text { NG }(1 \%)\end{array}$ & $\begin{array}{l}4.7 \\
\text { NG } \\
\text { NG }(14 \%)\end{array}$ & $\begin{array}{l}4.0 \\
\text { NG }(4 \%) \\
\text { NG }(6 \%)\end{array}$ & $\begin{array}{l}4.0 \\
\text { NG }(1 \%) \\
\text { NG }(4 \%)\end{array}$ & $\begin{array}{c}5.1 \\
\text { NG } \\
37\end{array}$ \\
\hline $\begin{array}{l}\text { Sinking } \\
\text { particles }\end{array}$ & $\begin{array}{l}1840 \\
\text { (10 m above } \\
\text { sea floor) }\end{array}$ & $\begin{array}{r}25 \\
3 \\
3\end{array}$ & $\begin{array}{r}1 \\
1 \\
180\end{array}$ & $\begin{array}{l}11 \\
\text { NG }(4 \%) \\
36\end{array}$ & $\begin{array}{l}8.6 \\
46 \\
14\end{array}$ & $\begin{array}{l}5.2 \\
\mathrm{NG} \\
7.7\end{array}$ & $\begin{array}{l}4.6 \\
\text { NG } \\
8.5\end{array}$ & $\begin{array}{c}5.7 \\
53 \\
7.4\end{array}$ \\
\hline Sediment & $\begin{array}{l}1850 \\
(1 \mathrm{~cm} \text { below } \\
\text { surface })\end{array}$ & $\begin{array}{r}25 \\
3 \\
3\end{array}$ & $\begin{array}{r}1 \\
1 \\
180\end{array}$ & $\begin{array}{l}-^{b} \\
N G(1 \%) \\
N G\end{array}$ & $\begin{array}{l}\text { NG }(1 \%) \\
\text { NG }(1 \%)\end{array}$ & $\begin{array}{l}- \\
- \\
-\end{array}$ & $\begin{array}{l}- \\
\text { NG }(2 \%) \\
\text { NG }(3 \%)\end{array}$ & $\begin{array}{l}- \\
\operatorname{NG}(2 \%) \\
190\end{array}$ \\
\hline Sediment & $\begin{array}{l}1850 \\
(5 \mathrm{~cm} \text { below } \\
\text { surface })\end{array}$ & $\begin{array}{r}25 \\
3 \\
3\end{array}$ & $\begin{array}{r}1 \\
1 \\
180\end{array}$ & $\begin{array}{l}- \\
\text { NG }\end{array}$ & $\begin{array}{l}- \\
\operatorname{NG}(<1 \%) \\
\operatorname{NG}(<1 \%)\end{array}$ & $\begin{array}{l}- \\
- \\
-\end{array}$ & $\begin{array}{l}- \\
\text { NG } \\
\text { NG }\end{array}$ & $\begin{array}{l}- \\
\mathrm{NG} \\
\mathrm{NG}\end{array}$ \\
\hline Sediment & $\begin{array}{l}1850 \\
(15 \mathrm{~cm} \text { below } \\
\text { surface })\end{array}$ & $\begin{array}{r}25 \\
3 \\
3\end{array}$ & $\begin{array}{r}1 \\
1 \\
180\end{array}$ & $\begin{array}{l}- \\
\operatorname{NG}(1 \%) \\
\operatorname{NG}(2 \%)\end{array}$ & $\begin{array}{l}\mathrm{NG}(2 \%) \\
\mathrm{NG}\end{array}$ & $\begin{array}{l}- \\
- \\
-\end{array}$ & $\begin{array}{l}- \\
\text { NG }(1 \%) \\
\text { NG }(1 \%)\end{array}$ & $\begin{array}{l}\text { NG } \\
\text { NG }(1 \%)\end{array}$ \\
\hline $\begin{array}{l}{ }^{a} \text { Based on } 5 \text { to } 7 \\
\text { increased signif } \\
{ }^{\circ} \text { Experiment no } \\
\text { YE = yeast extr } \\
\mathrm{NG}=\text { no growth } \\
\text { percentage divi }\end{array}$ & $\begin{array}{l}\text { d time-course } \\
\text { icantly above st } \\
\text { t done } \\
\text { act } \\
\text { ti no significant } \\
\text { ding cells incre }\end{array}$ & $\begin{array}{l}\text { experiments } \\
\text { arting level } \\
\text { increase ( }+\end{array}$ & ) in ba & l numbe & ve starting l & vel. For $N$ & $\begin{array}{l}\text { periment } \\
\text { ly }\end{array}$ & which \\
\hline
\end{tabular}


sions of homogenized fecal pellets and surface sediments from the 4120 and $4715 \mathrm{~m}$ stations are shown in Table 2. Results of similar experiments on samples from the $1850 \mathrm{~m}$ station are given in Table 3 . With only naturally-available substrates present, no significant bacterial growth was detected in any sediment sample under any of the incubation conditions tested. Increasing the total incubation period from $2 \mathrm{~d}$ (Table 2 ) to $7 \mathrm{~d}$ (Table 3) resulted in the occasional observation of small net gains in the percentage of dividing cells under deep-sea temperature and pressure. Enrichment with YE induced growth in 1 sediment sample under shallow water conditions (Table 2), but had no significant effect at low temperature or elevated pressure for any of the sediment samples tested (Table 2 and 3). Enrichment with chitin, however, induced a barophilic growth response at $3^{\circ} \mathrm{C}$ from bacteria in the $1850 \mathrm{~m}$ surface sediment sample (Table 3 ).

Results obtained with samples of fecal pellets from bottom-moored sediment traps (depths of 1840,3920, and $4695 \mathrm{~m}$ ) differed from those obtained with sediment core samples. Under shallow water conditions, significant bacterial growth occurred without substrate enrichment in the 2 samples of shallower origin. Additions of $Y E$ or chitin increased these growth rates and stimulated growth in the third and deeper sample. At the same pressure $(1 \mathrm{~atm})$ but lower temperature $\left(3^{\circ} \mathrm{C}\right)$ growth was not detected unless the sample was enriched with YE (Table 2). When these fecal pellet samples were pressurized, as well as chilled, substrate additions induced a bacterial growth rate or net gain in percent dividing cells that was equivalent to or greater than that measured at $1 \mathrm{~atm}$ and $3{ }^{\circ} \mathrm{C}$ (Table $2 \& 3$ ). Similar results were obtained for the sample containing a representative portion of all particulates intercepted by the $1840 \mathrm{~m}$ sediment trap, with 2 exceptions: under deep-sea temperature and pressure, significant growth occurred without substrate enrichment; and with additions of YE or chitin, 'deep-sea' doubling times ( 7.4 to $14 \mathrm{~h}$ ) were markedly faster than those measured at $3^{\circ} \mathrm{C}$ and atmospheric pressure ( $46 \mathrm{~h}$ to no growth) and almost as rapid as those measured at $25^{\circ} \mathrm{C}$ and $1 \mathrm{~atm}(4.6$ to $8.6 \mathrm{~h})$.

The most rapid doubling time in this study $(3.8 \mathrm{~h})$ was recorded for bacteria in the suspension of fecal pellets from near-surface waters when enriched with YE and incubated at $22^{\circ} \mathrm{C}$ and $1 \mathrm{~atm}$. No significant growth or net gain in percent dividing cells was measured in this sample when chilled or chilled and pressurized.

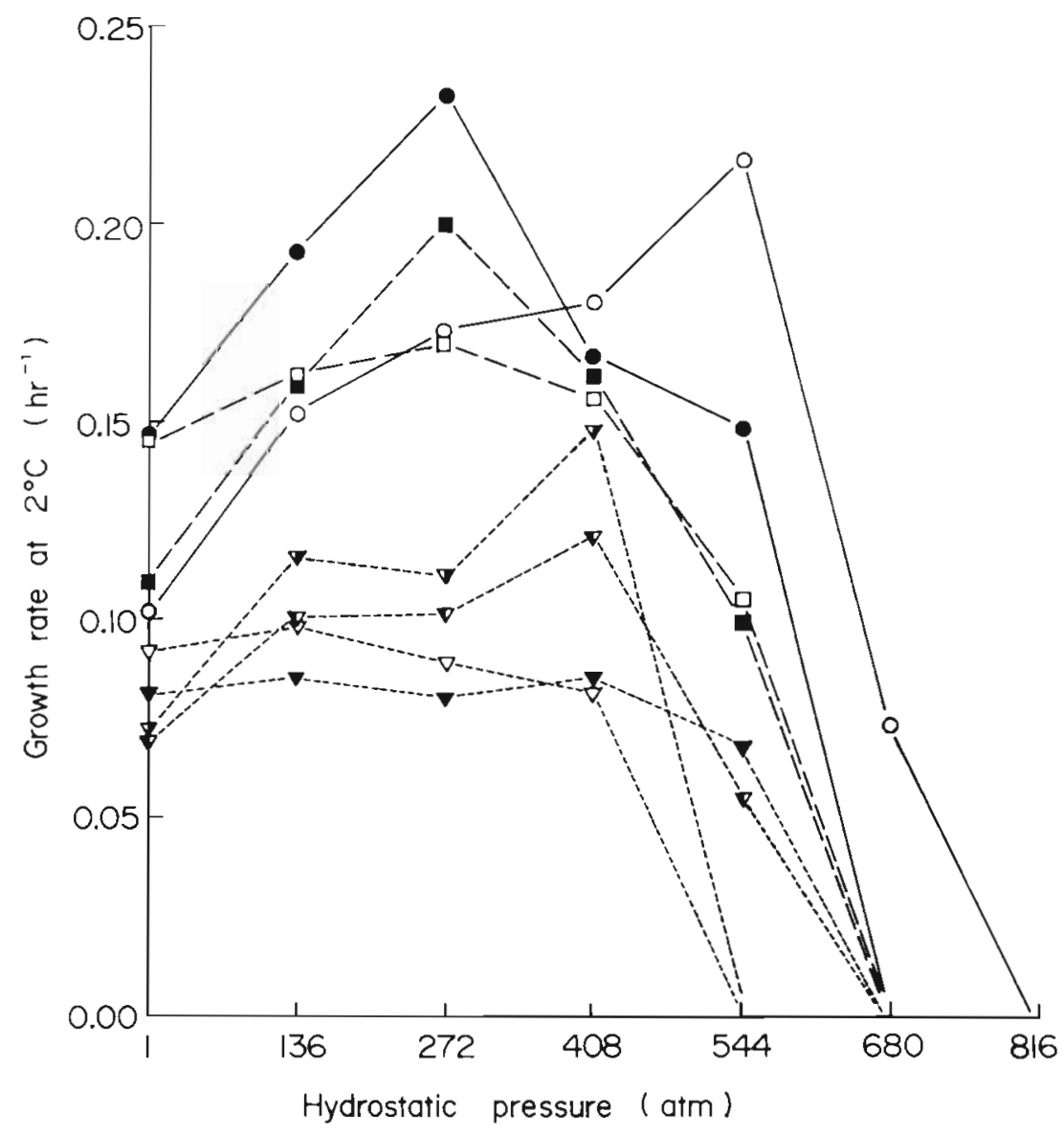

Fig. 1. Barophilic growth characteristics of bacterial strains BBS2 $(\square)$ and $3(\square)$, BBDT1 $(\nabla)$ and $2(\nabla), B B P 5(\nabla)$ and $6(\nabla)$, and BBG3 $(\bullet)$ and $4(0)$, isolated in pure culture from sediment trap (---), boxcore (- $)$, and holothurian gut (-) samples from station depths of 4120 and $4715 \mathrm{~m}$ in the Bay of Biscay 
Growth rates measured at $2^{\circ} \mathrm{C}$ for 8 strains of bacteria, isolated in pure culture from deep-sea samples collected at the 4120 and $4715 \mathrm{~m}$ stations, are plotted in Fig. 1 as a function of increasing hydrostatic pressure. All strains were barophilic or highly barotolerant, growing 1.1 to 2.2 times faster at elevated pressures than at atmospheric pressure, as similarly reported for other strains of deep-sea, barophilic bacteria (Jannasch et al. 1982, Yayanos et al. 1982, Deming et al. 1984). The most rapid doubling times (4.3 and $4.5 \mathrm{~h}$ ) and the strongest barophilic responses were demonstrated by the gut isolates (Strains BBG3 and 4).

\section{DISCUSSION}

Although recent progress in the development of microbiological methods has resulted in estimates of the in situ doubling times of natural bacterial assemblages in relatively accessible marine environments (Hagstrom et al. 1979, Karl 1979, Fuhrman \& Azam 1980, Ducklow et al. 1982), bacterial growth rates have not been measured in situ at depths greater than $2000 \mathrm{~m}$. In situ microbiological studies in the deep sea have focused instead on measurements of substrate utilization rates, using ${ }^{14} \mathrm{C}$-organic compounds and pressureretaining water samplers or remote-controlled sediment tripods (see review by Jannasch \& Taylor 1984). Results of these studies indicated that total utilization rates were 10 to 1000 times slower than rates measured under shallow water conditions and that only about $10 \%$ of any substrate utilized actually contributed to bacterial production or growth. By inference, bacterial growth rates in the deep sea must be quite slow.

Carlucci \& Williams (1978) estimated in situ doubling times of bacteria in the deep sea $(145 \mathrm{~h}$ at $1500 \mathrm{~m}$; $210 \mathrm{~h}$ at $5550 \mathrm{~m}$ ) on the basis of pure culture studies in which pelagic marine bacteria were isolated at atmospheric pressure and later returned to simulated in situ conditions of temperature, pressure, and substrate availability (unamended seawater). A similar study using bacteria selectively isolated under in situ conditions has not been attempted. Yayanos et al. (1982) reported growth rates for bacteria isolated under in situ temperatures and pressures, but the microorganisms were enriched from a specialized source (trapped, decomposing abyssal amphipods) and cultured in nutrient-rich broth. This study represents a first attempt to measure simulated in situ growth rates for natural bacterial assemblages associated with sinking particulates (primarily fecal pellets) and sediments in the deep sea.

The resulting rates must be viewed with caution for several reasons. Many were based on end-point experiments in which lag periods or rapid spurts of growth are not recognized. Experimental design would have selected for aerobic, heterotrophic bacteria in a population which, left undisturbed in situ, might have been more complex and heterogeneous in community structure and activity. Growth rates might have been influenced artificially, in unknown ways, by the necessity to homogenize the samples and, in the case of sediments, dilute them. On the other hand, potential bottle effects' (which can never be discounted completely) leading to overestimates of bacterial growth were minimal in these experiments, since unusually slow or no growth was measured in many of the samples, even after substrate enrichment and incubation for $7 \mathrm{~d}$. Furthermore, the unavoidable but brief period of decompression to which all samples were exposed during retrieval and handling did not prevent detection of significant populations of barophilic bacteria, since doubling times in some samples under in situ pressure were equivalent to or more rapid than those measured at atmospheric pressure, all other conditions being equal. Until better estimates can be obtained in situ, the bacterial doubling times reported here may be of some use in evaluating microbial activities and developing models of the abyssal benthic boundary layer (Rowe \& Gardner 1979, Rowe \& Deming in press). The rates calculated for a given sample under variable conditions are of immediate use on a comparative basis in assessing the origins of bacteria present in the deep sea, and their potential response to substrate enrichment.

From this perspective, some of the results of this study support current views on bacteria in the deep sea, as recently reviewed by Jannasch \& Taylor (1984), and some do not. Experimental data from the subsurface trap sample were in keeping with the view that surface-derived bacteria, settling through the water column with the flux of particulate matter, are severely limited in their activities at first by low temperature and at increasing depths by the combined extremes of low temperature and elevated pressure. Although reduced availability of utilizable energy sources may also limit surface-derived bacteria at great depth in the sea (Novitsky \& Morita 1978), results of experiments with such bacteria in this study indicate that restrictions imposed on their growth by deep-sea temperature and pressure cannot be overcome by the introduction of fresh energy sources in the form of yeast extract. It was not surprising that no bacteria were isolated in pure culture from the near-surface trap sample when deep-sea incubation conditions of $3^{\circ} \mathrm{C}$ and $410 \mathrm{~atm}$ and an enriched culturing medium were used.

Nor was it surprising that the slowest growth rates in this study were measured for bacterial populations in the deep-sea sediment samples incubated under in situ conditions. Growth in these samples was sufficiently 
slow to preclude detection of significant increases in the total bacterial number, even after enrichment with yeast extract and an extended incubation period of $7 \mathrm{~d}$. Thus, the in situ doubling times of bacteria in deep-sea sediments must measure in weeks or months, in keeping with earlier views developed on the basis of in situ measurements of substrate utilization rate in similar sediments (Jannasch 1979).

That enrichment of deep-sea sediment samples with yeast extract failed to stimulate more rapid bacterial growth under deep-sea temperature and pressure is reminiscent of the behavior of surface-derived bacteria in the deep sea. However, other results are inconsistent with the interpretation that most of the bacteria in these sediment samples originated in shallow water: (1) barophilic bacteria, capable of doubling every $6 \mathrm{~h}$ in nutrient broth under in situ temperature and pressure, were isolated readily from the sediment samples; and (2) enrichment with chitin, rather than yeast extract, induced measurable bacterial growth under in situ temperature and pressure (doubling time of $190 \mathrm{~h}$ ) in a sediment sample from $1850 \mathrm{~m}$, when no growth was detected at atmospheric pressure, all other conditions being equal. No general conclusions can be drawn from a single chitin-enrichment experiment and no other precedent exists in the literature for bacteria in relatively shallow sediment $(1850 \mathrm{~m})$ requiring in situ pressure for optimal growth; nevertheless, the detection of this barophilic growth response argues strongly for the predominant role of locally-adapted bacteria in sediment processes, as has already been proposed for particle-associated processes in the water column at a similar depth (Karl et al. 1984, Silver et al. 1984). Clearly, detection of this response may also be linked specifically to the remineralization of chitin, a refractory substance commonly available in the deep sea and a substrate of choice for future experiments.

Ultimately, it is the results of experiments with samples of deep-sea fecal pellets and sinking particulates, rather than with surface-water pellets or bottom sediments, that do not fit conventional views of limited microbial biomass and activity in the deep sea. A comparison of bacterial concentrations in the various samples examined (Table 1) reveals that fecal pellets, and probably sinking particulates in general, represent an enriched source of bacteria in the benthic environment. Note that simulated in situ growth in the undiluted seawater suspension of particulates trapped for $2.6 \mathrm{~d}$ at $1840 \mathrm{~m}$ (doubling time of $36 \mathrm{~h}$ ) was too slow to account for the observed bacterial concentration $\left(1.44 \times 10^{8}\right.$ bacteria $\left.1^{-1}\right)$ being 20 times higher than expected in seawater at that depth. These particulate sources of bacteria, regardless of their in situ activities, probably serve as a quality food supply for benthic animals (Honjo 1978, Morita 1979, Rowe \& Gardner
1979, Khripounoff \& Sibuet 1980). The fecal pellets, in particular, may have already passed through or originated from the digestive systems of pelagic animals and planktonic forms (Honjo 1978), some of which are known to concentrate and feed at surprisingly high rates in the benthic boundary layer (Wishner \& MeiseMunns 1984). An abyssal gut origin for the fecal pellets collected at depth in this study is supported by the isolation of barophilic bacteria from carefully rinsed pellets. It is interesting to note, however, that bacteria isolated directly from an invertebrate gut still show a stronger barophilic response (as also observed by Jannasch \& Wirsen 1984) and grow more rapidly than those isolated from the pelagic environment, all other conditions being equal (Fig. 1).

Evidence that many of the bacteria associated with particulates reaching the ocean floor were indigenous to the deep sea, and not surface-derived, came from experimental data for each of the samples prepared from deep trap collections, as well as from the pure culture work. Exemplary data was obtained with a chitin-enriched suspension of sinking particulates intercepted at a depth of $1840 \mathrm{~m}, 10 \mathrm{~m}$ above seafloor. In this sample, the bacterial doubling time was rapid at $25^{\circ} \mathrm{C}$ and 1 atm $(5.1 \mathrm{~h})$, considerably slower at $3^{\circ} \mathrm{C}$ and $1 \mathrm{~atm}(53 \mathrm{~h})$, but almost as rapid again under deep-sea temperature and pressure $(7.4 \mathrm{~h})$ as under shallowwater conditions. These results can be interpreted as evidence that many surface-water bacteria do reach bottom depths via particulate matter, but that at depth they are slowed in their activities primarily by low temperature. Remarkably rapid growth under in situ temperature and pressure, following sample enrichment with chitin, suggests the presence of a separate population of indigenous deep-sea bacteria as the dominant agents in the remineralization of organic carbon, even when highly refractory, at ocean depth.

This study is part of an ongoing research program in the deep sea that, along with the work of many others, may eventually confirm or refine the various interpretations and conclusions drawn here. However, it seems reasonable on the basis of the current data set to propose that particulate organic matter arriving at the ocean floor provides focal points for intense microbial activity in the deep sea, not unlike those already detected by others at mid-oceanic depths.

Acknowledgements. I thank Daniel Desbruyeres and Cathy Warsh for the opportunity to join their cruises; the officers and crew of the 'Jean Charcot' and 'Mt. Mitchell' for excellent support; Gil Rowe and Alexis Khripounoff for sharing sediment trap samples; Art Yayanos for use of his laboratory facilities; Leslie Somers for laboratory assistance; John Baross for the gift of purified chitin; and Rita Colwell for courage. This research was supported by NSF grants PDF-8166007 and OCE-8300371 and NOAA grant NA82AA-D-00064 


\section{LITERATURE CITED}

Carlucci, A. F., Williams, P. M. (1978). Simulated in situ growth rates of pelagic marine bacteria. Naturwissenschaften 65: 541-542

Deming, J. W, Colwell, R. R. (1982). Barophilic bacteria associated with digestive tracts of abyssal holothurians. Appl. environ. Microbiol. 44: 1222-1230

Deming, J. W., Tabor, P. S., Colwell, R. R. (1981), Barophilic growth of bacteria from intestinal tracts of deep-sea invertebrates. Microb. Ecol. 7: 85-94

Deming, J. W., Hada, H., Colwell, R. R., Luehrsen, K. R., Fox, G. E. (1984). The ribonucleotide sequence of 5S rRNA from two strains of deep-sea barophilic bacteria. J. gen. Microbiol. 130: 1911-1920

Dietz, A. S., Yayanos, A. A. (1978). Silica gel media for isolating and studying bacteria under hydrostatic pressure. Appl. environ. Microbiol. 36: 966-968

Ducklow, H. W., Kirchman, D. L., Rowe, G. T (1982). Production and vertical flux of attached bacteria in the Hudson River plume of the New York Bight as studied with floating sediment traps. Appl. environ. Microbiol. 43: 769-776

Fellows, D. A., Karl, D. M., Knauer, G. A. (1981). Large particle fluxes and the vertical transport of living carbon in the upper $1500 \mathrm{~m}$ of the northeast Pacific Ocean. Deep Sea Res. 28: 921-936

Fuhrman, J. A., Azam, F. (1980). Bacterioplankton secondary production estimates for coastal waters of British Columbia, Antarctica, and California. Appl. environ. Microbiol. 39: 1085-1095

Fuhrman, J. A., Azam, F. (1983). Adaptations of bacteria to marine subsurface waters studied by temperature response. Mar. Ecol. Prog. Ser. 13: 95-98

Gowing, M. M., Silver, M. W. (1983). Origins and microenvironments of bacteria mediating fecal pellet decomposition in the sea. Mar. Biol. 73: 7-16

Hagstrom, A., Larsson, U., Horstedt, P., Normark, S. (1979). Frequency of dividing cells, a new approach to the determination of bacterial growth rates in aquatic environments. Appl. environ. Microbiol. 37: 805-812

Hobbie, J. E., Daley, R. J., Jasper, S. (1977). Use of Nuclepore filters for counting bacteria by fluorescence microscopy. Appl. environ. Microbiol. 33: 1224-1228

Honjo, S. (1978). Sedimentation of materials in the Sargasso Sea at a $5367 \mathrm{~m}$ station. J. mar. Res. 36: 469-492

Jannasch, H. W. (1979). Microbial turnover of organic matter in the deep sea. Bioscience 29: 228-232

Jannasch, H. W., Taylor, C. D. (1984). Deep-sea microbiology. Ann. Rev. Microbiol. 38: 487-514

Jannasch, H. W., Wirsen, C. O. (1984). Variability of pressure adaptation in deep sea bacteria. Arch. Mikrobiol. 139 $281-288$

Jannasch, H. W., Wirsen, C. O., Taylor, C. D. (1982). Deep-sea bacteria: isolation in the absence of decompression. Science 216: 1315-1317

Karl, D. M. (1979). Measurement of microbial activity and growth in the ocean by rates of stable ribonucleic acid synthesis. Appl. environ. Microbiol. 38: 850-860

Karl, D. M., Knauer, G. A., Martin, J. H., Ward, B. B. (1984) Bacterial chemolithotrophy in the ocean is associated with sinking particles. Nature, Lond. 309: 54-56

Khripounoff, A., Sibuet, M. (1980). La nutrition d'echinodermes abyssaux. I. Alimentation des holothuriens. Mar. Biol. 60: 17-26

Morita, R. Y. (1979). Deep-sea microbial energetics. Sarsia 64: 9-12

Novitsky, J. A., Morita, R. Y. (1978). Possible strategy for the survival of marine bacteria under starvation conditions. Mar. Biol. 48: 289-295

Rowe, G. T., Deming, J. W. (1985). The role of bacteria in the turnover of organic carbon in deep-sea sediments $\mathrm{J}$. mar. Res. (in press)

Rowe, G. T., Gardner, W. D. (1979). Sedimentation rates in the slope water of the northwest Atlantic Ocean measured directly with sediment traps. J. mar. Res. 37: 581-600

Schwarz, J. R., Yayanos, A. A., Colwell, R. R. (1976). Metabolic activity of the intestinal microflora of a deepsea invertebrate. Appl. environ. Microbiol. 31: 46-48

Sibuet, M., Monniot, C., Desbruyeres, D., Dinet, A., Khripounoff, A., Rowe, G., Segonzac, M. (1984). Benthic populations and trophic characteristics in the Demerara abyssal basin (Atlantic Ocean). Oceanologica Acta 7: 345-358

Silver, M. W., Gowing, M. M., Brownlee, D. C., Corliss, J. O (1984). Ciliated protozoa associated with oceanic sinking detritus. Nature, Lond. 309: 246-248

Williams, P. M., Carlucci, A. F., Olson, R. (1980). A deep profile of some biologically important properties in the central North Pacific gyre. Oceanologica Acta. 3: 471-476

Wirsen, C. O., Jannasch, H. W. (1975). Activity of marine psychrophilic bacteria at elevated hydrostatic pressures and low temperatures. Mar. Biol. 31: 210-208

Wishner, K. F., Meise-Munns, C. J. (1984). In situ grazing rates of deep-sea benthic boundary-layer zooplankton. Mar. Biol. 84: 65-74

Yayanos, A. A., Dietz, A. S., Van Boxtel, R. (1982). Dependence of reproduction rate on pressure as a hallmark of deep-sea bacteria. Appl. environ. Microbiol. 44 $1356-1361$ 